\title{
Political science in exceptional times: Finnish scholars responding to three crises of the 2010s
}

\author{
Petri Koikkalainen ${ }^{1}$
}

Accepted: 16 March 2021 / Published online: 10 June 2021

(c) The Author(s) 2021

\begin{abstract}
This article focuses on Finnish political scientists' contributions to the public debate at a time when the relationship between academia and the government was tenser than usual. More specifically, it addresses the public roles and relevance of political scientists during three salient political crises of the 2010s: the annexation of Crimea by Russia in 2014 and the war in Donbass, the so-called European migrant crisis beginning in 2015, and the failure of major Finnish governance reform in 2019. I examine scholars' interventions into them in a corpus of eighty articles collected from the online journal Politiikasta and use qualitative content analysis to study the polarisation of their views and the style of interventions, including scholars' relationship with the government. I discuss the visibility and impact of political science in the context of gender and seniority of researchers, the presence of political science in the Finnish media, in general, and against other social-scientific disciplines, and with the other countries studied in this Special Issue.
\end{abstract}

Keywords Finland · Institutional reform · Migration · Political science · Qualitative content analysis $\cdot$ Science journalism $\cdot$ Ukraine

\section{Introduction}

In publicly funded university systems, academics can find themselves in a dilemma that may be particularly strongly felt in political science. Researchers need to respond to the government's incentives to secure financial resources for their work and to maintain the discipline's position in a highly competitive field, but the traditional work ethic of political scientists demands, when necessary, challenging the same government that provides a lion's share of their research funding. While, in theory, there is not necessarily a contradiction between researchers securing government funding and conducting

Petri Koikkalainen

petri.koikkalainen@ulapland.fi

1 Faculty of Social Sciences, University of Lapland, Yliopistonkatu 8, P.O. Box 122, 96101 Rovaniemi, Finland 
critical political research, in practice the question whether researchers can maintain a genuinely critical stance if the government has the means to punish them financially is subject to frequent debate.

This article examines how Finnish political scientists handled the dilemma by studying their texts as responses in the public debate to crises, which involved the government's important and sometimes controversial political decisions. The relationship between academia and the government was conflictual due to fiscal austerity in universities and public disagreements. The three crises discussed were all major topics which echoed in Finnish politics in the 2010s: the annexation of Crimea by Russia in 2014 and the subsequent war in Donbass; the so-called European migrant crisis beginning in 2015; and the failure of major domestic governance reform in 2019. The crises involved varying combinations of domestic and foreign politics; urgent policy issues and failure of long-term planning; and they all highlighted ideological cleavages between political parties and their supporters. By studying the academics' responses, this article elucidates their roles as experts and commentators.

The analysis utilises the theoretical framework of this Special Issue (see Figure 1 in Real Dato and Verzichelli, this Special Issue, eps.). The research data elucidate especially the dimension of partisanship (polarisation of views), while I discuss visibility and impact with the help of more indirect evidence. Observable partisanship includes clear normative positions on political issues that may challenge the positions of political parties or the sitting government, but political scientists can also express normative views without making the issue directly party-politicised. Partisanship may also touch the balance between at least seemingly neutral 'scientific' arguments and 'normative' arguments openly based on moral or political preference. I study the dimensions of partisanship by applying qualitative content analysis to eighty texts published in the online journal Politiikasta ('On Politics', www.politiikasta.fi), published and edited by political scientists under the auspices of the Finnish Political Science Association (FiPSA). I also discuss scholars' visibility both within the studied material and in the more general Finnish context, paying attention to factors such as academic seniority, gender, and opportunities offered by different media. I cannot evaluate the impact of scholars' interventions directly in the light of this data, but I will discuss some of its typical routes and potential conditions of success.

The dataset as a whole shows how Finnish political scientists as a community responded to crisis and moved to the working mode of 'difficult times'. If compared with studying political scientists' appearances in mainstream media, the Politiikasta corpus reveals the priorities of political scientists instead of commercial or publiclyowned media houses and their editors. Moreover, a significant part of the material consists of contributions of junior researchers and researchers probably not so well aligned with the priorities of mainstream media.

\section{The involvement of Finnish political scientists in the public sphere}

Resembling its Nordic neighbours, Finland ranks high in academic freedom (Kinzelbach et al. 2020). The relations between academia and public authorities are traditionally comparatively unproblematic, but in the studied period, the relationship 
was tenser than in the years before. That situation followed from the unprecedented budget cuts in universities during the first half of Sipilä's government term (2015-2019) and the government's biting critiques of academics, whose public interventions allegedly obstructed a major reform in social and healthcare and regional government, a case exemplified in this article. ${ }^{1}$

Finnish political scientists frequently intervene in public debate. In the 2018 PROSEPS survey of European Political Scientists (Vicentini et al. 2019), nearly all of the thirty-five respondents agreed - sixteen of them fully, seventeen somewhatthat "political scientists should engage in public debate since this is part of their role as social scientists", with only two respondents somewhat disagreeing. Of individual Finnish respondents, $62.9 \%$ had participated in public debates in the media over the last 3 years, which is slightly above the European average of $60.3 \%$. They also perceived their participation as consequential, since when asked about their discipline's public visibility, Finland ranked fourth of the twenty-four countries, slightly behind Sweden, Denmark and Norway (Vicentini et al. 2019).

The number of Finnish respondents was not very large. The PROSEPS survey respondents, however, were all political scientists reached through the FiPSA networks, like most contributors (and all editors) of Politiikasta. Hence, there is some probable overlap between the survey respondents and the authors of the eighty articles analysed (I cannot confirm this because of the anonymity of the survey). Methodologically, the point is that together the survey and content analysis based on the Politiikasta corpus provide some comprehensive and multifaceted material for the study of the attitudes and reactions of the Finnish political science community to political crises.

The research questions focus on how Finnish political scientists positioned themselves in the above described politically charged situation. Did they take partisan roles, supporting specific political positions, brokering roles where they proposed solutions or alternatives to problems and conflicts, or observer roles, where they did not take sides (see Real Dato and Verzichelli, in this issue). Did they support or criticise the government? Did their texts strictly adhere to the scientific standards, or were they written in a more approachable and popularised style? I will address these questions in the context of the studied crises. I will show that when the crises do not touch the basic aspects of the political community itself (and there are, for example, no referenda that would further secure the division of opinions), the situation may lead to milder polarisation of views than in some other cases studied in this Special Issue, for example, Greece, Italy, Spain, and the UK, each with their particular emphases, and hence be relatively favourable to 'observer' and 'broker' roles and also junior writers, instead of producing only a few partisan opinion leaders.

\footnotetext{
1 The Sipilä government included the Centre Party, National Coalition (conservative) and the Finns Party (populist). The scale of the cuts counted from 2013 to 2016 was circa 10 per cent in terms of budget and workforce reductions (Sivistystyönantajat 2013, 2015, 2016). About the government's verbal quips against the academics, see Sintonen (2015).
} 


\section{Case selection}

The following three topics are the cases of this study: (1) Crisis in Ukraine, 2014 onwards; (2) Migration to Europe, 2015-2016; and (3) Social and Healthcare and Regional Government Reform, 2015-2019. They all were highly visible topics of the national debate and included major stakes for the leading political forces. Therefore, also scholars' interventions took place on a politically divided landscape. The Ukraine and Migration cases were policy-related crises resulting from exogenous influence. The Social and Healthcare and Regions case was an institutional crisis produced by the failure of a major domestic governance reform. The main events of the Ukraine crisis remained outside Finland, whereas the Migration crisis started exogenously but developed significant endogenous dynamics. Unlike the first two cases, the governance reform failure was purely endogenous.

If compared with the other country cases in this Special Issue, two things stand out. First, even if the crises studied divided the opinions of political parties (especially Migration and Social and Healthcare and Regions), they did not touch the fundaments of the political community such as its territorial integrity, EU membership or core constitutional issues (cf. Spain, Italy, Greece, and the UK); nor did they involve a referendum. Regarding Social and Healthcare and Regions, a successful reform could have produced governance changes approaching the scale of the Italian constitutional vote, but a referendum was never a serious option. Second, we cannot read the Finnish debate in the context of a real illiberal turn of politics. Even if the strained relations between politicians and academics created a unique situation for a while, that seems bygone, all formal conditions regarding democracy and the freedom of speech remained unchanged.

\section{Crisis in Ukraine, 2014}

The annexation of Crimea in February 2014 and the conflict in Donbass escalating in April-June 2014 highlighted the ambiguity of Finland's relations with Russia. For example, the onset of the crisis prompted the re-emergence of the question whether Russia could threaten Finnish territory, too, in order to advance its strategic interests. Finland is not a NATO member, but its ties to the NATO structures are close (Pyykönen 2017). Applying for a NATO membership has been debated but prevented by lack of sufficient majorities. Regarding the European Union, Finland's recent governments have supported the common European policy of sanctions against Russia, even if the counter-sanctions have harmed parts of Finnish industries. Nevertheless, there are also politicians, civil servants and businesspersons who have argued in favour of maintaining friendlier bi-lateral relations with Russia. Finland's identity either as a decidedly Western or 'European' country, or a country that resides 'between the East and West', has been a hot topic for decades. Since Finland's EU membership in 1995, the pro-Western interpretation has been stronger than in, for example, the Cold War years. (e.g. Forsberg 2018). 


\section{Migration to Europe, 2015-2016}

In 2015 and 2016, Finland received close to 40,000 immigrants chiefly from Iraq, Afghanistan and Syria. That number was above the European average in proportion to Finland's population of five and a half million. Local reactions ranged from willingness to volunteer to expressions of xenophobia. A populist party was in government between 2015 and 2019 (until June 2017, the Finns Party; after June 2017, Blue Reform party). The government introduced amendments to legislation and regulations to pursue a stricter immigration policy (Wahlbeck 2019). In the aftermath of the crisis, populist themes included culture and identity issues such as Islam, the status of women, and the claimed inability of some nationalities to integrate into Finnish society. On the extreme nationalist right, we can find racist and neo-Nazi definitions of 'Finnishness' with willingness to direct action (Kotonen 2019). The Finns Party, then in government, changed their leader in May 2017 from Timo Soini to the more outspokenly 'immigration-critical' Jussi Halla-aho. This led to a party split, which allowed Soini and fellow Finns ministers to remain in government under the new group Blue Reform. The group lost the next election in 2019, but the Finns Party ranked second with only one seat behind the Social Democrats, who, at the time of writing, are the largest party of PM Sanna Marin's government coalition.

\section{Social and healthcare and regional government reform}

Finland does not have elected regional government between the state and municipalities. The municipalities, presently totalling 311 , have significant autonomy, but face difficulties in providing equal public services, most apparently in specialised hospital care, where small municipalities struggle to cover the costs (Saltman and Teperi 2016.). Since the early 2000s, several governments have tried to revamp the governance model. In 2015, Sipilä's government declared the reform of social welfare and healthcare and regional government their main goal. The government proposed eighteen counties for regional government and a 'freedom of choice' principle that allowed the outsourcing or privatising of health services. Especially, the left parties, then in opposition, criticised these proposals. Tight timetables and critiques about the cost-effectiveness and constitutionality of the proposals characterised law-making (Kangas and Kalliomaa-Puha 2018). This increased tension between the government and expert organisations, including the universities. The reform failed after a critical report by the parliament's constitutional committee in late February 2019. Sipilä admitted failure and declared the mid-term resignation of his government on 8 March 2019. 


\section{Data and method}

FiPSA established Politiikasta ('On Politics') in 2012 with the deliberate aim of increasing the discipline's visibility, media contacts, and social impact. The majority of the FiPSA board members in the early 2010s, as well as of Politiikasta editors and sub-editors, were early-to-mid-career scholars rather than full professors, who undoubtedly wanted to assist also younger and less experienced researchers gain access to the general public. Politiikasta may help visibility and impact in at least three ways. Search engines find its articles quite easily, and since a national scientific society guarantees their status, journalists, for example, feel safe to use the material. Articles are promoted actively in Facebook and Twitter, and occasional public talks and seminars have been organised around them. Finally, Politiikasta material can enter the 'jungle drum' of journalists and other experts, and especially in a smallish country, such networks occasionally lead to wider publicity.

Edited by political scientists who are also its largest group of contributors, the journal publishes mainly short and popularised texts, often as quick reactions to topical issues. ${ }^{2}$ On 27 April 2020, the journal had 1176 archived texts, 700 daily average downloads, and around 6.000 followers on Facebook and 5.000 on Twitter. The breadth of the Politiikasta material enables comprehensive analyses of positions held in the political science community if compared with other media. The style of the texts is generally slightly more specialised than, for example, guest articles in mainstream newspapers. I assembled the text corpus in August 2019, which consists of eighty texts: thirty-one on Ukraine, forty on Migration, and nine on Social and Healthcare and Regions. ${ }^{3}$ The topics received significant coverage, since the texts made more than seven per cent of all published items between April 2012 and August 2019. The number of articles varies significantly between the cases, but it includes all articles published on these cases. Given the journal's role as the public 'voice' of the Finnish Political Science community, we can also read these quantitative differences as an indication of their interests on these themes, which is a research finding by itself. It may also be that the more dramatic nature of the Ukraine and Migration cases as armed conflict and humanitarian crisis simply provoked more discussion than the Social and Healthcare and Regions case, which was a 'mere' failure of a major domestic policy reform. I retrieve texts from the Politiikasta archive under the Finnish-language tags for 'Ukraine's crisis', 'immigration', 'social and healthcare reform', and 'regional elections'. The tags appeared reliable, since open Google searches with the same and closely related keywords and the journal's name gave almost identical results.

\footnotetext{
2 Information received from editor-in-chief Mikko Poutanen, 17 January 2020. Politiikasta has won two national awards: in 2016 the recognition award of the Finnish Association for Scholarly Publishing and in 2019 the science communication award of the Finnish Association of Science Editors and Journalists.

3 Texts with identifiable authors other than the journal's editorial team were included, leaving out one text without author information and two interviews written anonymously by the journal's editorial team. Two texts in the Migration case were in spoken video format. Details of the text corpus are available upon request to the author.
} 
Table 1 Authors by gender, seniority, and discipline [first 6 rows]; Texts by number of authors, language, publication year (Politiikasta corpus, 80 texts). Source: Author's calulation

\begin{tabular}{lrrrr}
\hline & Ukraine & Migration & Social and health & Total \\
& 21 authors, 31 texts & 47 authors, 40 texts & 12 authors, 9 texts & 52 \\
\hline Female authors & 13 & 32 & 7 & 28 \\
Male authors & 8 & 15 & 5 & 47 \\
Junior academics & 11 & 34 & 2 & 33 \\
Senior academics & 10 & 13 & 10 & 36 \\
Political academics & 18 & 16 & 2 & 44 \\
Non-pol. scientists & 3 & 31 & 10 & 65 \\
Single-authored & 31 & 28 & 6 & 15 \\
Multi-authored & 0 & 12 & 3 & 72 \\
Language Finnish & 23 & 40 & 9 & 8 \\
Language English & 8 & 0 & 0 & 5 \\
2013 & 4 & 1 & 0 & 21 \\
2014 & 20 & 1 & 0 & 14 \\
2015 & 5 & 9 & 0 & 9 \\
2016 & 0 & 9 & 0 & 14 \\
2017 & 1 & 7 & 6 & 11 \\
2018 & 1 & 3 & 0 & 6 \\
2019 & 0 & & 3 & 5 \\
\hline
\end{tabular}

While I could classify virtually all authors as scholars, several were not political scientists by their affiliation. However, political scientists made all publishing decisions and also did the editorial work. The journal's variety of approaches and authors reflects the traditionally broad Finnish definition of valtio-oppi, ${ }^{4}$ political science, which includes also political theory and philosophy, international relations, and overlaps with parts of contemporary history and public administration. The presence of authors from the neighbouring fields is probably indicative of the increasing multidisciplinarity of research projects, even if we cannot generalize observations from this corpus. Notably, none of the authors gave economics as their affiliation, suggesting a degree of separation between debating fora. The research setting also enabled searching for contrasts between political scientist and non-political scientist authors.

In the following table, the top six rows give the numbers of all individuals who were authors or co-authors of the text corpus. Figures in the lower rows show the distributions of published texts (Table 1).

In the table, junior scholars are $\mathrm{PhD}$ researchers and postdocs; senior scholars are senior lecturers, docents, professors and equivalent. In the whole corpus, the majority of authors were female and junior, which was reversed for seniority in Social and

\footnotetext{
4 A somewhat direct translation of German "Staatslehre" or Swedish "statskunskap". The discipline was institutionalised fairly early during the 1920s-1930s; FiPSA was founded in 1935.
} 
Healthcare and Regions. Among all authors, there were slightly more non-political scientists than political scientists. We can explain this tendency by the multidisciplinary perspectives adopted by Politiikasta to the Migration and Social and Healthcare and Regions cases. Regarding timing, publications in the Ukraine case concentrated heavily on the first half of the year 2014, a total of eighteen, which included the annexation of Crimea in February and the escalation of the Donbass conflict in April-June. In Migration, the publishing peak was during the most intense phase of the 'migrant crisis' of 2015-2016. All contributors to this topic until March 2016 were junior; senior scholars stepped in only during the aftermath of the crisis. The share of multi-authored texts notably increased towards the end of the period. In Social and Healthcare and Regions, the first texts appeared in 2017, when the government's initiatives were already well underway. The last three articles from April 2019 followed the failure of the reform and the government's resignation.

The relatively balanced distributions in gender and seniority among those who intervened in public debate are in some contrast to the other country examples of this Special Issue; perhaps most notably, Spain, Italy, Greece and the UK. An obvious explanation for this is the medium Politiikasta itself, which was designed to include otherwise potentially 'invisible' researchers. As indicated by the PROSEPS survey results, Finnish political scientists are otherwise relatively visible in mainstream media, and they are frequently interviewed on topics such as elections, government policy, changes of public political opinion, and international relations and global politics. A generation ago, the archetypal media scientist was probably a senior male professor giving detailed comments of the election result, but it is fair to assume that the image of the profession as well as the topics covered have become more diverse, a development Politiikasta was designed to assist. The activity of the authors varied, but overall, the corpus results from the work of a large and diverse group of scholars instead of few outstandingly active ones. In all cases combined, there were seventy-seven different authors, ${ }^{5}$ the clear majority of whom were authors of only one text in one case. In Ukraine, one author (male, junior) contributed four texts, one (male, junior) three texts, and seven authors two texts. The highest number of contributions by a single author (female, junior), five texts, was in Migration, with one author (male, junior) publishing three texts and four authors two texts. In Social and Healthcare and Regions, three authors (one female and two males, all senior) contributed to two texts. In the light of these figures, and in contrast to some other countries (e.g. Spain), no individual scholars dominated the discussion in any of the cases.

The research method combines theory-directed (or deductive) and content-based (or inductive) qualitative content analysis. In a theory-directed first phase (cf. Jahn, 2011), I operationalised the research questions into codes that I assigned to all texts, describing, (1) the level of academic specialisation; (2) political and normative positions; (3) relationship to government, and (4) the authors' discipline. In a content-based second phase, I constructed six types of intervention, broadly similar to

\footnotetext{
5 Three authors contributed to two different topics. Therefore, the sums of male and female, junior and senior, political scientist and non-political scientists are 80 instead of 77 in the previous table.
} 
textual genres. The analysis drew on the internal qualities of the texts, focusing "not so much on the [quantifiable] content of a communication as rather on its underlying intentions or its presumable effects on the audience", to quote one of the pioneers of the method (Kracauer 1952: 638).

\section{Finnish political scientists in public debate and the types of interventions}

\section{Overall characteristics of the three cases}

In my analysis, partisanship decomposes into three elements: the normative stance of the articles, their relation to government, and the use of scientific components. In the 'normative stance', policy recommendation refers to a policy view or suggestion directed to some public authority, such as the Finnish government or the EU. I classified more general normative views, and those not directed to any identified authority, as other normative position. Observer texts are without a clear normative position. 'Relation to national government' registers whether texts were explicitly supportive or critical of the current government. In 'role of science', specialist texts are based on published research, research observations or literature reviews, or they utilise scientific concepts and theories much more than the average text, or are based on the author's significant expertise on specialised fields such as foreign policy, public law, or medicine. Generalist texts stylistically resemble non-specialist journals and are approachable to the lay reader, but may include some scientific vocabulary. I also divided authors of the texts according to discipline into political scientists and non-political scientists based on Politiikasta's author information. This classification revealed notable differences between the cases, the combined results of which are shown in Table 2.

Policy recommendations, other normative positions and observer texts occurred with nearly similar frequency in grand total figures, but individual cases behaved differently. In the Ukraine case, observer texts were in the majority, while policy recommendations and normative positions were more common in the other two cases; policy recommendations in Social and Healthcare and Regions, in particular. Also, the distribution between specialist and generalist texts was remarkably even with the notable exception of Social and Healthcare and Regions, raising the grand total number of specialist texts above the generalist ones. In contrast to the two previous classes of data, a clear majority of the texts did not take a clear position for or against the government, but criticism was significantly more common than support in Migration and Social and Healthcare and Regions, in particular. In the light of the data, we cannot assume that the use of scientific components would always lead to more neutral positioning of the texts. Often, it was to the contrary, since authors with demonstrable expertise apparently felt more confident in providing policy recommendations or criticising the government.

The differences between political scientists and non-political scientists were not outstanding, except for the Ukraine case, where policy recommendations and normative positions, as well as support and critique of the government, were 


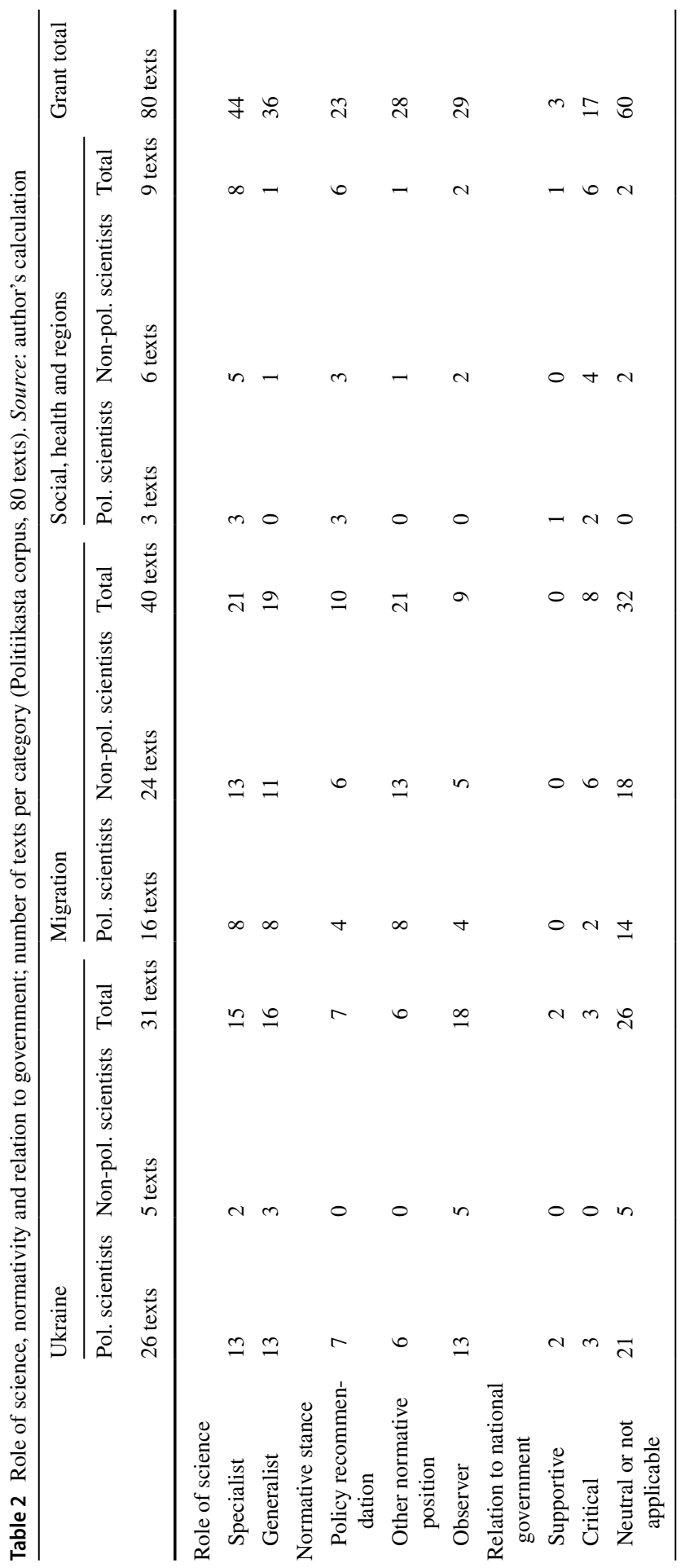

s. 
exclusively the domain of political scientists, which includes IR specialists. This suggests that foreign policy analysis is a specialised field where the threshold for non-specialist normative intervention is high. The comparatively high number of government-critical non-political-scientist texts in the Migration case consists mainly of critiques against the government's practices in various specialised policy areas.

In the Ukraine case, the early observer and generalist texts published in 2013-2014 were mostly attempts to comprehend and contextualise the rapidly escalating situation. The role of junior scholars was prominent. Senior scholars stepped in later with policy recommendations and stronger normative views, which mostly favoured the Western and multilateral institutions such as the European Union, NATO-with an outspoken defence of Finnish NATO membership by one author, or the Organisation for Security and Co-operation in Europe OSCE. Three texts criticised the 'Western' approach and advocated a more cautious line with Russia, but operated rather on the level of discursive or ideological analysis than directly challenging the government. The two texts classified as supporting the government were by the same person. Non-political scientist authors were mostly historians.

In the Migration case, too, the rapidly developing situation during 2014-2016 first garnered attention from junior scholars with research or personal experience directly relevant to the topic. Their contributions, classified mostly as generalist and observer, included reports from several foreign countries. Texts with explicit policy recommendations all appeared in 2016 or later. Specialist texts built on studies of administrative processes and legal definitions, linguistic analyses regarding the migrants' role in media, and participatory observation. About half of the articles dealt with political populism. Five texts expressed attitudes towards the Finnish government, all critical. Critical normative views about administrative processes and legal definitions occurred commonly without directly blaming the government, possibly in an attempt not to further politicise the situation. However, most texts on populism presented, at least implicitly, critiques of the current populist forces, of which the Finns Party was in government since 2015. Non-political scientist authors represented fields such as social policy, public law and administrative science, which was often reflected in their topic choices and policy recommendations.

The Social and Healthcare and Regions case significantly differs from the other two cases. The total number of texts related to this case was only nine, but most contributors were senior. As in the other two cases, seniority was often combined with policy recommendations and normative positions. Critiques against the Sipilä government were common and resembled what experts had presented throughout the government term 2015-2019. The last three texts, all published in spring 2019, were diagnostic texts concentrating on the reasons for failure. Almost all texts were classified as specialist, building on existing research or established expertise of the authors. An interesting feature is the small number of political scientist commentators of the regional government reform-a core area of political science. However, the two political scientists contributing were recognised senior experts. Nonpolitical scientist authors represented social policy, law and medicine, which was reflected in their topic choices and terminology. 


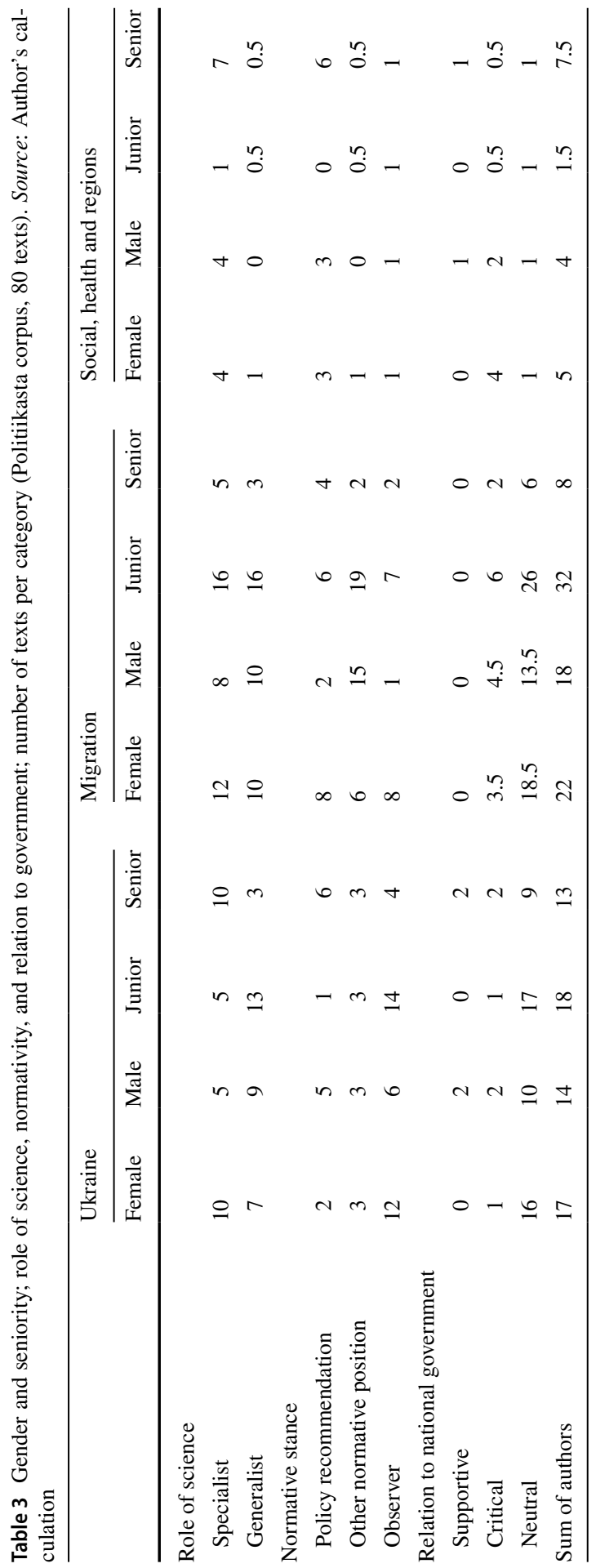

称 
The following Table 3 summarises specialist and generalist writing styles, policy recommendations and other normative positions, and support and critique of government according to the authors' gender and academic seniority.

In the above table and Table 4, I coded gender, seniority and discipline (Table 4) using the value of 0.5 for multi-authored texts with both male and female, junior and senior, political scientist and non-political scientist authors. Thus, the total number of texts in each case remains constant and comparable with the previous tables, but some of the decimal values end with, 5. Most figures in the table represent small groups of texts and do not allow reliable generalisations. However, some trends may be observed. Senior authors frequently used expert writing styles combined with policy recommendations and normative statements, including critique or support of the government. Normatively neutral observer texts were more frequent among junior authors, but in the Migration case, they, too, frequently presented normative statements and criticised the government. Some typical writer roles already emerge, such as senior policy experts in the Ukraine and Social and Healthcare and Regions cases. Conversely, and especially in the early stages of the Ukraine and Migration cases, junior authors provided background information and contextual analysis written in an observer role, often elaborating on issues that mainstream journalists had covered in less detail.

\section{Types of intervention}

Some writing strategies or textual genres appeared in the data several times. Utilising the previous classifications, this subsection divides the corpus into six typical groups described in the order of their magnitude. They are not an exhaustive description of the data but rather an excursion into some of its qualities, and also differences of opinion or emphasis between scholars. The types outlined here are not mutually exclusive, since texts often had multiple functions, for example, policy analyses combined with future prognoses. Therefore, some texts have two classifications, but no more than two. The sum of grand totals for all types is 106 based on eighty texts analysed, so twenty-six texts have a double classification. The table presents the sub-divisions according to case, discipline, gender and seniority, corroborating the previous observations on linkages between, for example, juniority and contextualising reporting style, and seniority and policy advice.

\section{Country or background analyst (thirty-five texts)}

Texts elucidating contemporary or historical context without strong normative or political positions were typical of especially the early stages of the Ukraine and Migration crises. They often reflected the authors' research and personal background. These texts were based on observation of contemporary events more often than on published peer-reviewed research, but could dig deeper into the background of the subject than daily newspaper reporting, suggesting that specialised knowledge of countries and cultures may be more common in universities than media 


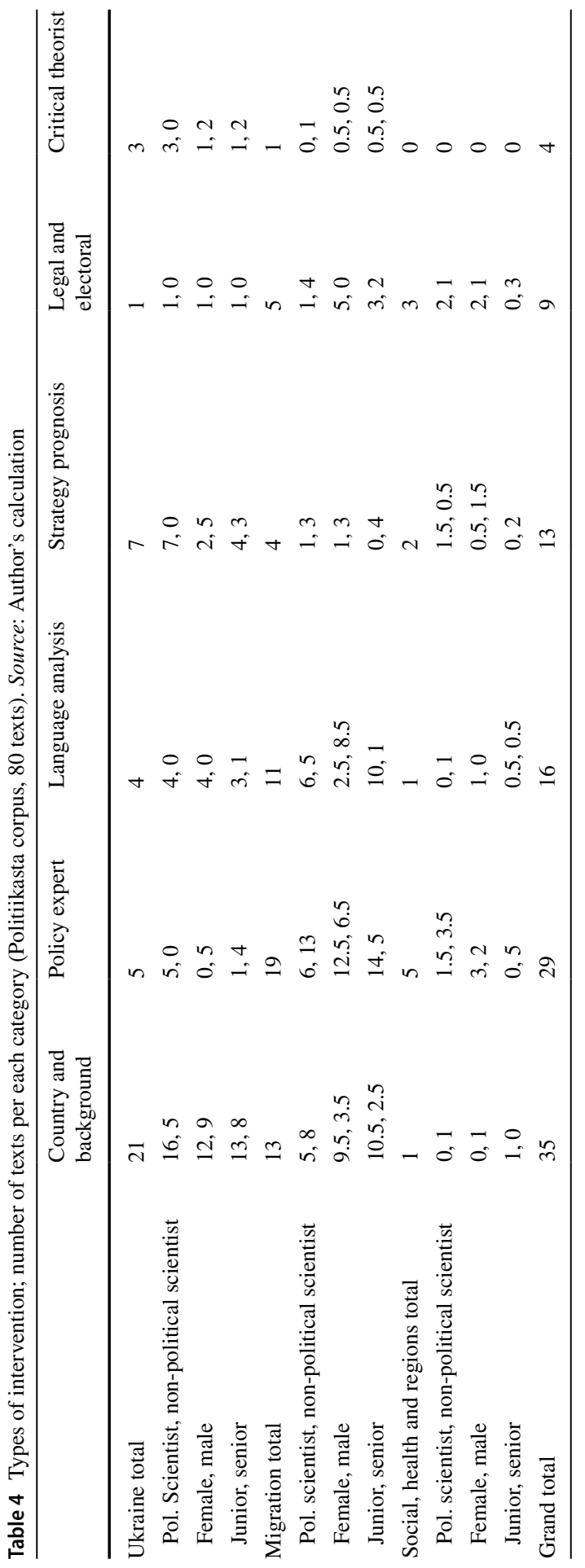

s. 
newsrooms. Political scientists, junior, and female scholars were in the majority. Personal attachment to the case was often made clear, as the excerpt below suggests:

In spring 2012, I spent two months in Crimea interviewing the members of two Crimean youth organisations for my MA thesis $\left(\mathrm{U}_{10}^{6}\right.$ : female, junior, political scientist). ${ }^{7}$

Many articles interpreted contemporaneous news events against particular national contexts, making Finnish readers see the situation 'from their point of view':

President Macron visited Calais in January [2018]. That deed was loaded with symbolism and it was intended to communicate-two days before meeting with Theresa May-that "the border is closed and Calais is no longer a destination for immigrants" (M31: female, junior, political scientist).

Contextual elaboration did concern only foreign countries, but there were also several articles elaborating the historical or other background of domestic policy issues.

\section{Policy expert (twenty-nine texts)}

Texts often diagnosed the causes behind the success or failure of various policies, and authors often had significant experience in research and other expert roles. Political scientists constituted a clear majority over non-political scientists in the Ukraine case, but comprised a minority in the other two cases. Senior scholars were over-represented in all cases. In Ukraine, all authors were male, but females constituted the majority in the other two cases. The normative attitudes in this text type were often critical, and the authors usually did not hesitate to name the government or prime minister when seeking reasons for failure:

Prime Minister Sipilä pushed for Finland's largest social policy reform with the smallest possible majority [...] A seemingly authoritarian style of leadership was introduced, leading to poor and hasty law-making: let's do this now and fix it later (S7: three senior, male and female, non-political scientists).

Another area of prominent policy expertise was Finland's foreign policy. Typically, senior authors recommended policy options with foreign countries or international organisations, as this writer with a long background in civil service and research:

To the extent that Ukraine's solutions are satisfactory to key players, the operation of OSCE may well get started as an international regional institution and a provider of good services (U24: male, senior, political scientist).

Texts addressed various policy areas and were often written by researchers from disciplines such as public administration, social policy, and public law. Their

\footnotetext{
${ }^{6}$ The letters U, M and S refer to the Ukraine, Migration and Social and Healthcare \& Regions cases respectively. The numbers are assigned according to publishing dates, lower numbers representing earlier publication.

7 Unless mentioned otherwise, all text excerpts are author's translations from Finnish texts.
} 
specialisations often showed in topic choice, but their use of theory and other academic components did not generally differ much from political scientists. Normative positions were usually critical, but critique was more commonly targeted against administrative procedures and regulations than leading politicians directly. Often, criticism was accompanied by policy recommendations, thus approaching a broker role.

\section{Analyst of political language (sixteen texts)}

Many texts exhibited their authors' interest in the political aspects of language, including the value-ladenness of everyday concepts and the discursive and ideological force of language. Some articles were based on published research, while others utilised discourse analytic, rhetoric or conceptual viewpoints developed in previous research to new issues. The texts often did not provide policy recommendations, but many of them shared a generally critical or emancipatory purpose of revealing the force of linguistic conventions. This excerpt is from a post-doc researcher who published three texts with a linguistic focus:

In [Finns Party MP] Hakkarainen's rhetoric, immigrants - that is, young Arab and Muslim men - have an immutable, natural essence, derived from their alleged ancestor, Ishmael (M20: male, junior, political scientist).

Text writers paid attention to newly introduced, politically motivated vocabulary such as 'welfare surfer', found in populist rhetoric. Sometimes analyses concentrated on complex linguistic units such as metaphors and analogies. The following author warns against reading Finland's situation in 2014 in the light of the Winter War between Finland and Russia in 1939-1940 alone, even if the cases shared similarities that can be presented as analogies:

In the Finnish debate, the Winter War has become a compulsive analogy, because then - just like now in Ukraine-Russia demanded territory from Finland and eventually attacked (U18: female, junior, political scientist).

Most texts were authored by political scientists and junior scholars, and a linguistic approach was most commonly used in the Migration case.

\section{Strategic, prognostic analyst (thirteen texts)}

The making of prognoses in the sense of forecasting events not observed already did not appear frequently in the corpus. More often than that, scholars engaged in 'strategic' considerations about the long-term effects of various policy choices. Political scientists were a clear majority in all prognostic and strategic texts, and authors were mostly male and senior. Approaching forecasting, there were some attempts to derive probable outcomes from historical precedents or existing obligations, as in the following excerpt that pays attention to Russia's historical adherence to international law, published in March 2014 before Russia's official involvement in the Donbass conflict: 
Direct military intervention, as we understand it in international politics, is therefore an excluded option, even though Russia will not leave Ukraine to its own fortunes (U8: female, junior, political scientist).

The text below combined situation analysis and strategic recommendations, covering Finland's foreign policy after the Ukraine crisis had escalated, however, differing in conclusions from the previous example and putting Finland's NATO membership on the table:

Finland needs tools. Emerging transatlantic relations have a role that needs to be seriously considered. NATO must not only be a negative buzzword. Well considered, its salad table has a lot to offer (U11: male, senior, political scientist).

A common future-oriented way of writing was that of making policy recommendations based on diagnoses of the success and failures of previous policy. This was a writing strategy often used by experienced scholars especially in Social and Healthcare and Regions.

\section{Electoral or legal expert (nine texts)}

The commentary of elections and political institutions is a traditional public role for political scientists in Finland. However, the topics of this study did not directly link with elections with the exception of regional government and other constitutional issues in Social and Healthcare and Regions. Political rights and participation entered the debate in Migration. The number of texts was rather small with male and female authors, senior and junior academics, political scientists and public law experts. Texts usually had strong background in research or other forms of expertise, such as committee work. Below, a professor emeritus gives qualified support to the Sipilä government's regional government reform initiative:

In fact, the now planned regional government produces political proportionality better than decision-making in municipalities or parliamentary elections (S1: male, senior, political scientist).

In the Migration case, interest in political participation increased after migrants who entered the country in 2015-2016 had settled and started engaging in the various functions of society. This sparked the interest of researchers of political activism and turnout:

In our recent study published in Yhteiskuntapolitiikka [Social and Public Policy], we look at Somali participation in Finland as voters on the one hand, and association activists on the other (M17: three females, junior and senior, political scientists).

The authors often took a critical role or a broker role, suggesting political and legal solutions to overcome problems. Their own normative preferences were usually not on the foreground, but we can often detect support for representative institutions, equal treatment of individuals, and human rights. 


\section{Critical theorist (four texts)}

Scholars also engaged in radical social critique, questioned hegemonic views, and described issues through alternative theoretical lenses. These interventions shared with the analysts of political language an interest in the political force of seemingly neutral social conventions, but criticised prevailing hegemonies often more directly. Here, a professor emeritus of IR questions the 'Western hegemony' in the prevailing interpretations of the Ukraine crisis:

Looking at the ongoing crises and the attitude of the Western world to them, one cannot avoid the idea that the West lives in the past, or in a self-constructed fairy tale of its ideal world. In that fairy tale, the West is still trying to force the bad guys of the war to live up to its own value standards, imagined to be universal (U29: male, senior, political scientist).

Occasionally, the radical foundations of political concepts such as democracy and sovereignty, worn in daily use, were rethought in ways that sought to transcend politics as 'business as usual'. Familiar practices of governance were described through alternative theoretical lenses, in an attempt to show it in a different light:

Strict adherence to security guidelines creates a Foucauldian paradox, where technical guidance and rules, such as professional secrecy, is used to strengthen a sense of security [...] As we add to the illusion of security, we also increase distrust and create new fears (M34: five females and one male, junior and senior, non-political scientists).

The number of texts in this category was too small to make reliable generalisations regarding gender or seniority.

\section{Conclusion}

When addressing the three crises, scholars dealt with politically touchy issues. In a publicly funded university system such as Finland's, party-political interests affect science policy and resourcing through the government programmes. Against the backdrop of the then-strained relations between the government and academia, an imaginable outcome could have been political scientists' reluctance to speak in order to secure their discipline's resources. In contrast to the cases of Hungary and Israel in this Special Issue, Finnish scholars openly criticised their government, but not for light reasons, often invoking broad and universal values, such as human rights, representative democracy, and the value of human life.

Still, if compared with some other countries, partisanship among scholars remained comparatively low. An explanation may be that even if the crises divided Finnish party-political opinion, the underlying issues did not touch the basic aspects of the political community such as its territorial integrity (Spain), the reach of national sovereignty and the country's commitment with the 
European project (Greece, UK) or basic political institutions (Italy). In the light of these other cases, such 'fundamental' issues appear to lead also to increasing scholarly partisanship, where high visibility often connects with academic seniority and male gender. In the absence of such clear-cut decision-making situations that may also include a referendum, scholars' even critical views appear to be more often incorporated into less partisan observer and broker roles.

In addressing the crises, the online journal Politiikasta performed various functions. For junior researchers, it could be a comparatively low-threshold media where to experiment with the popularisation of research. For established scholars, it was a place where they could address topical issues rapidly and develop their views more extensively than, say, in mainstream media interviews. The material published in Politiikasta stands in some contrast to the general tendency observed in this Special Issue where a senior, usually male-dominated 'mediatic minority' occupies much more space than junior, often female 'invisible majority'. In the three crises studied, the general visibility of political science was at its highest during the crisis peaks that corresponded with the peak numbers of texts in the Politiikasta corpus, but otherwise visibility was medium to low.

As a final note, the general perception in the scholarly community is that presence first gained in Politiikasta often gave rise to more general visibility of the same topics - and often the same authors - in national mass media. There is no evidence that any of the Politiikasta writings would have had direct impact regarding national policy. Nevertheless, some contributors have visible public roles and various committee and advisory roles. Therefore, ideas developed in Politiikasta may be reflected in impactful advice given in, for instance, government committees. In the actual texts, seniority often went together with policy recommendations, strategic considerations and often critique of the government, which all could carry an impact. This combination was most pronounced in Social and Healthcare and Regions. Junior scholars often wrote observer texts that deepened contexts and opened new perspectives. Nevertheless, junior scholars also took normative positions, criticised the government, and made policy recommendations, all this most visibly in Migration. In terms of the number of articles and their spread, Politiikasta certainly increased the access points of political scientists to extra-academic audiences during the studied period of 2013-2019. While its direct impact is harder to assess, the online journal as a whole appears to have successfully promoted the preferences for public engagement that Finnish political scientists clearly expressed also in the PROSEPS survey of 2018 .

Funding Open access funding provided by University of Lapland.

Open Access This article is licensed under a Creative Commons Attribution 4.0 International License, which permits use, sharing, adaptation, distribution and reproduction in any medium or format, as long as you give appropriate credit to the original author(s) and the source, provide a link to the Creative Commons licence, and indicate if changes were made. The images or other third party material in this article are included in the article's Creative Commons licence, unless indicated otherwise in a credit line to the material. If material is not included in the article's Creative Commons licence and your intended use is 
not permitted by statutory regulation or exceeds the permitted use, you will need to obtain permission directly from the copyright holder. To view a copy of this licence, visit http://creativecommons.org/licen ses/by/4.0/.

\section{References}

Forsberg, T. 2018. Finland and NATO: Stategic Choices and Identity Conceptions. In The European Neutrals and NATO: Non-alignment, Partnership, Membership?, ed. A. Cottey, 97-127. London: Palgrave MacMillan.

Jahn, D. 2011. Conceptualising Left and Right in Comparative politics: Towards a Deductive Approach. Party Politics 17 (6): 745-765.

Kangas, O., and L. Kalliomaa-Puha. 2018. ESPN Flash Report 2018/2. European Social Policy Network.

Kinzelbach, K., I. Saliba, L. Spannagel, and R. Quinn. 2020. Free Universities: Putting the Academic Freedom Index Into Action. Global Public Policy Institute. Available at https://www.gppi.net/media/ KinzelbachEtAl_2020_Free_Universities.pdf. Accessed 27 April 2020.

Kotonen, T. 2019. The Soldiers of Odin Finland: From a Local Movement to an International Franchise. In Vigilantism Against Migrants and Minorities, ed. T. Bjørgo and M. Mareš, 241-256. Abingdon: Routledge.

Kracauer, S. 1952. The Challenge of Qualitative Content Analysis. The Public Opinion Quarterly 16 (4): 631-642.

Pyykönen, J. 2017. Nordic Partners of NATO: How Similar are Finland and Sweden within NATO Cooperation?. The Finnish Institute of International Affairs FIIA, Report 48.

Saltman, R.B., and J. Teperi. 2016. Health Reform in Finland: Current Proposals and Unresolved Challenges. Health, Economics, Policy and Law 11 (3): 303-319.

Sintonen, K. 2015. Kaiken Maailman Dosentit. Entry to Professoriblogi (Professor Blog), Finnish Union of University Professors, 4 December 2015. Available at https://blogi.professoriliitto.fi/kirsti-sinto nen/kaiken-maailman-dosentit/. Accessed 27 April 2020.

Sivistystyönantajat (Finnish Education Employers) (2013), (2015), (2016) Tilastojulkaisu: Yliopistot [Statistics Publication: Universities].

Vicentini, G., L. Verzichelli, J. Real-Dato, and I. Andreadis. 2019. Social Visibility and Impact of European Political Scientists. Working Group 3 Report. Available at http://proseps.unibo.it/wp-content/ uploads/2019/10/WG3.pdf. Accessed 27 April 2020.

Wahlbeck, Ö. 2019. 'To Share or Not to Share Responsibility? Finnish Refugee Policy and the Hesitant Support for a Common European Asylum System'. Journal of Immigrant \& Refugee Studies 17 (3): 299-316.

Publisher's Note Springer Nature remains neutral with regard to jurisdictional claims in published maps and institutional affiliations.

Petri Koikkalainen is associate professor of political science at the University of Lapland, Finland. His research interests include Finnish and Nordic politics, political theory, and the history of political thought. For the term 2015-2021, he served in the Executive Committee of the European Consortium for Political Research (ECPR). 